OPEN ACCESS

Edited by:

Xu Yu,

Massachusetts General Hospital and Harvard Medical School, United States

Reviewed by:

Giuseppe Novelli,

University of Rome Tor Vergata, Italy

Ahmed Rakib,

University of Tennessee Health

Science Center (UTHSC),

United States

Talha Bin Emran,

Begum Gulchemonara Trust

University, Bangladesh

${ }^{*}$ Correspondence:

Ramcés Falfán-Valencia

rfalfanv@iner.gob.mx

Specialty section:

This article was submitted to

Viral Immunology,

a section of the journal

Frontiers in Immunology

Received: 29 October 2020

Accepted: 16 March 2021

Published: 01 April 2021

Citation:

Fricke-Galindo I and Falfán-Valencia $R$ (2021) Genetics Insight for COVID-19 Susceptibility and Severity: A Review.

Front. Immunol. 12:622176.

doi: 10.3389/fimmu.2021.622176

\section{Genetics Insight for COVID-19 Susceptibility and Severity: A Review}

\author{
Ingrid Fricke-Galindo and Ramcés Falfán-Valencia*
}

HLA Laboratory, Instituto Nacional de Enfermedades Respiratorias Ismael Cosío Villegas, Mexico City, Mexico

Coronavirus disease (COVID-19) presents a broad spectrum of clinical manifestations ranging from an asymptomatic to a severe clinical course. The host genetic background influence on the susceptibility and outcome of multiples infectious diseases has been previously reported. Herein, we aimed to describe relevant identified genetic variants and those potentially related to the inter-individual variability of COVID-19 susceptibility and/or severity considering the physiopathological pathway of the disease The HLA-A*25:01, $-B^{\star} 15: 27,-B^{\star} 46: 01,-C^{\star} 01: 02$, and $-C^{\star} 07: 29$ alleles have been associated with COVID-19 susceptibility; while HLA-A*02:02, $-B^{\star} 15: 03$, and $-C^{*} 12: 03$ have been identified as lowrisk alleles. Variants in cytokine genes such as IL1B, IL1R1, IL1RN, IL6, IL17A, FCGR2A, and TNF could be related to disease susceptibility and cytokine storm, and/or COVID-19 complications (e.g., venous thrombosis). Several variants in ACE2 and TMPRSS2 affecting the expression of the receptors related to COVID-19 have been associated with the disease susceptibility and risk factors. Finally, two GWAS have identified the loci 3p21.31 (LZTFL1, SLC6A20, CCR9, FYCO1, CXCR6, and XCR1) and 9q34.2 (ABO) with COVID-19 severity. Heterogeneous results in the association of genetic variants with COVID-19 susceptibility and severity were observed. The mechanism of identified riskgenes and studies in different populations are still warranted.

Keywords: COVID-19, genetics, ACE2, HLA, SNV, SARS-CoV-2

\section{INTRODUCTION}

The Coronavirus Disease 2019 (COVID-19) is a severe respiratory and systemic disease caused by the novel Severe Acute Respiratory Syndrome Coronavirus 2 (SARS-CoV-2). The first cases of the new disease were reported in Wuhan, Hubei Province of China, and it has spread quickly to the rest of the worldwide population. Until March 3, 2021, countries have reported to the World Health Organization (WHO) a total of 114,428,211 confirmed cases of COVID-19, a cipher that unfortunately includes $2,543,755$ deaths (1).

COVID-19 is a complex disease that presents a broad spectrum of clinical manifestations ranging from an asymptomatic to a severe clinical course (Figure 1). This infection is considered a systemic disease involving the cardiovascular, respiratory, gastrointestinal, neurological, hematopoietic, and immune systems (4-6). The mortality rate reported ranges between 1-7\% (7); respiratory failure, septic shock, multiorgan failure, and cardiac arrest are considered the leading causes of death $(8,9)$. 


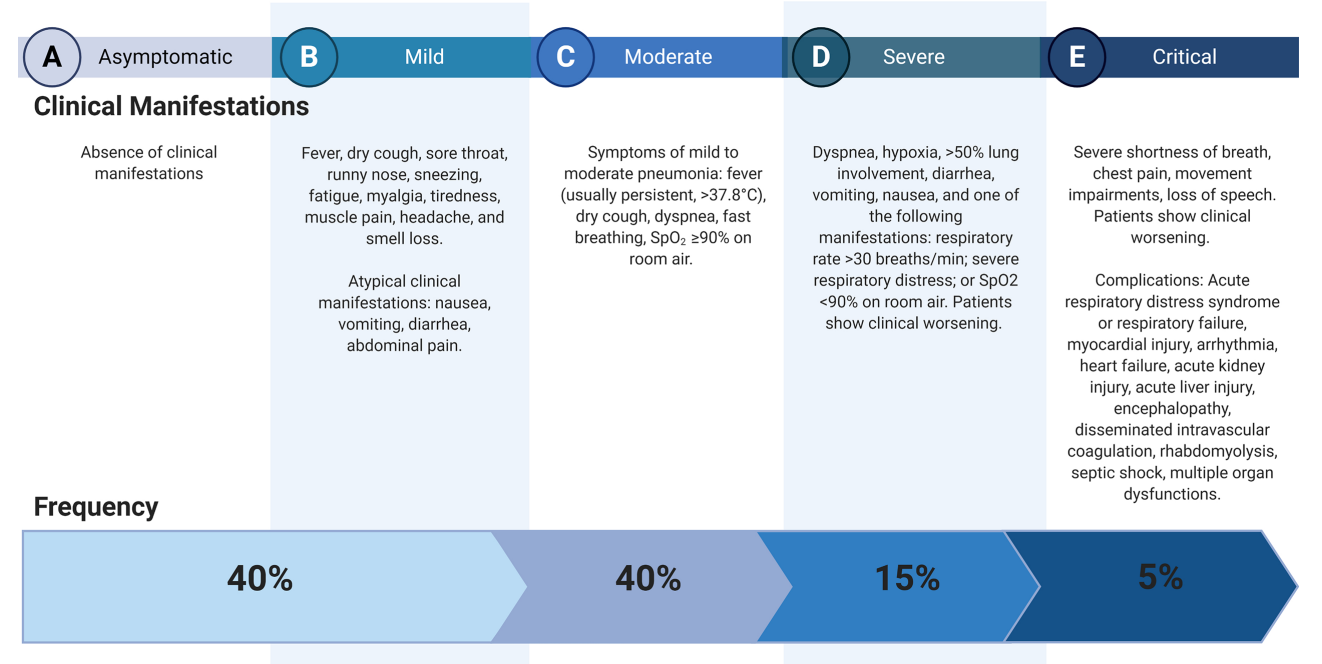

FIGURE 1 | Clinical courses of COVID-19. Data (2) and Clinical management of COVID-19, interim guidance (3). Created with BioRender.com.

Acute Respiratory Distress Syndrome (ARDS) is developed by $41.8 \%$ of patients with COVID-19, mainly in those with comorbidities such as diabetes mellitus, hypertension, cardiovascular disease, and chronic kidney disease (10). Myocardial injury (including acute coronary syndrome, myocarditis, heart failure, hypotension, shock, and sepsis) is strongly associated with death and severe cases of the COVID-19 $(9,11)$, and it has been explained by the presence of AngiotensinConverting Enzyme 2 (ACE2) in myocardial cells and the cytokine storm produced after the SARS-CoV-2 infection (12). COVID-19 has also been associated with coagulation abnormalities (e.g., disseminated intravascular coagulation or thrombotic microangiopathy) related to a massive release of plasminogen activators as a product of inflammation-induced endothelial cell injury (13). Other complications of COVID-19, such as acute kidney injury, co-infection with another pathogen, thromboembolism, and/or multiorgan failure, have been reported $(3,9)$.

Given the broad spectrum of COVID-19 clinical course and complications, identifying risk factors that could predict the disease's severity would improve the infected patients' outcome. In this sense, older age, smoking, hypertension, diabetes mellitus, cardiac disease, chronic lung disease, and cancer have been associated with COVID-19 severity and death $(3,14)$. Nevertheless, these conditions do not explain the total cases of the severity and mortality of COVID-19; therefore, genetic variations influencing the clinical outcome could be considered. Also, regional differences in the frequencies of some COVID-19 clinical manifestations have been observed. For instance, fever and dyspnea were more frequent in patients from Wuhan $(91.7 \%$ and $21.1 \%$, respectively) than in patients from other regions of China (78.1\% and 3.80\%) (15).

Moreover, olfactory disturbance or loss of smell seems to be a common symptom among Europeans (16) and Americans from the United States (17), but not for Asians (18). Such variations could be due to demographic, cultural, and dietary habit differences, but genetic variations exist worldwide.

\section{SARS-CoV-2 Protein Interaction and Immune Response}

The knowledge of virus interaction with human proteins and the immune mechanism against the infection is crucial to identifying target genes to study the susceptibility and severity of COVID-19. The SARS-CoV-2 infects alveolar epithelial cells through receptormediated endocytosis. The SARS-CoV-2 spike protein (S) binds to the ACE2 receptor, which is expressed in several organs, including the lung, heart, kidney, and intestine (19). Following the receptor binding, the virus enters the host cell cytosol through aciddependent proteolytic cleavage of the $S$ protein, in which some proteases, including Transmembrane Serine Protease 2 (TMPRSS2) and Cathepsin L (CTSL), cleave to S domains to mediate membrane fusion and virus infectivity $(20,21)$.

The innate immune response to SARS-CoV-2 infection comprises a mechanical barrier including cells of the pulmonary epithelium and tissue-resident macrophages and dendritic cells. Both immune cells express pattern recognition receptors which can detect Pathogen-Associated Molecular Patterns (PAMPs) and Damage-Associated Molecular Patterns (DAMPs) (22), which triggers the activation of cytoplasmic NOD-Like Receptor family and Pyrin domain-containing 3 protein (NLRP3) inflammasome pathway (23). The inflammasome activation in macrophages, epithelial cells, and endothelial cells releases pro-inflammatory cytokines, Interleukin (IL)-1 $\beta$ and IL-18, which produce neutrophilia and leukopenia, contributing to the pathogenic inflammation responsible for the severity of symptoms of COVID-19 (24, 25). Besides, Toll-Like Receptor (TLR)3, TLR7, TLR8, and TLR9, sensing viral RNA, activate the Nuclear Factor kappa B (NF-KB) pathway and a high number of pro-inflammatory cytokines with a significant role in initiating virus-induced 
inflammation (26). The increased secretion of the proinflammatory cytokines and chemokines IL-6, Interferongamma (IFN- $\gamma$ ), Monocyte Chemoattractant Protein-1 (MCP-1), and IFN- $\gamma$-induced Protein 10 (IP-10) attracts immune cells, notably monocytes and $\mathrm{T}$ lymphocytes, but not neutrophils, from the blood into the infected site, explaining the lymphopenia and the increased neutrophil-lymphocyte ratio seen in around $80 \%$ of patients with SARS-CoV-2 infection (27).

Commonly, recruited cells scrub the infection in the lung, the immune response subsidies, and the patient recovers. Nevertheless, in patients with severe COVID-19, a dysfunctional immune response occurs, triggering a cytokine storm, in which an increase of IL-2, IL-6, IL-7, IL-10, Granulocyte ColonyStimulating Factor (G-CSF), IP-10, MCP-1, Macrophage Inflammatory Protein $1 \alpha$ (MIP- $1 \alpha)$ and Tumor Necrosis Factor-alpha (TNF- $\alpha$ ) in plasma blood levels are observed (27, 28). Although the mechanism leading to the cytokine storm remains unknown, the interferon signaling pathway's antagonists have been considered (27). Levels of cytokines can explain some of the COVID-19 complications, such as septic shock and multiorgan failure due to TNF- $\alpha$ increase; moreover, cytokine storm is also found in older patients and those with comorbidities, which are considered risk factors for the disease complication $(11,27)$.

As an antiviral mechanism, antigen-presenting cells are involved in presenting antigenic peptides through the Major Histocompatibility Complex (MHC) class I and class II molecules to CD8+ and CD4+ T cells (29). Both T and B cell responses against SARS-CoV-2 can be detected in the blood around 1 week after the onset of COVID-19 symptoms (27). CD8+ $\mathrm{T}$ cells are activated, start cell division and clonal expansion, and develop virus-specific effectors and memory $\mathrm{T}$ cells to cause lysis to the infected cells. B cells can be activated directly by the virus recognition and by the interaction with CD4+ T cells. Immunoglobulin (Ig) M antibody can be detected at the early stages of infection, while IgG antibodies are then produced for lifelong immunity (25).

Given the well-known influence of the host genetic background in the susceptibility and outcome of multiples infectious diseases, including coronavirus infections (30), we aimed to describe relevant identified genetic variants and those potentially related to the inter-individual variability of COVID-19 susceptibility and/ or severity considering the physiopathological pathway of the disease.

The clinical outcome variation to life-threatening pathogens shows the functional genetic diversity of the immune response, differences in the pathogen's interaction with host proteins, and/ complex gene-gene and gene-environment interactions $(28,29)$. Therefore, the genes described for COVID-19 susceptibility and severity were classified if they were related to the immune system, to the SARS-CoV-2 receptor, or other genes reported to be associated with the disease susceptibility or its complications (Figure 2).

We performed a literature search of relevant articles in scientific databases (i.e., PubMed, WHO, GenBank, dbSNP, HUGO Gene Nomenclature Committee) from July 2020 to February 2021. The quest includes the following search terms: 'COVID-19', 'genetics', 'genomics', 'HLA', 'disease susceptibility', 'ACE2', 'disseminated intravascular coagulation', 'venous thrombosis'. According to the data relevance, articles were selected, and those studying the SARS-CoV-2 genome and preprints were excluded. Information was analyzed and summarized; thus, the analysis and conclusions of those results are reported in the present review.

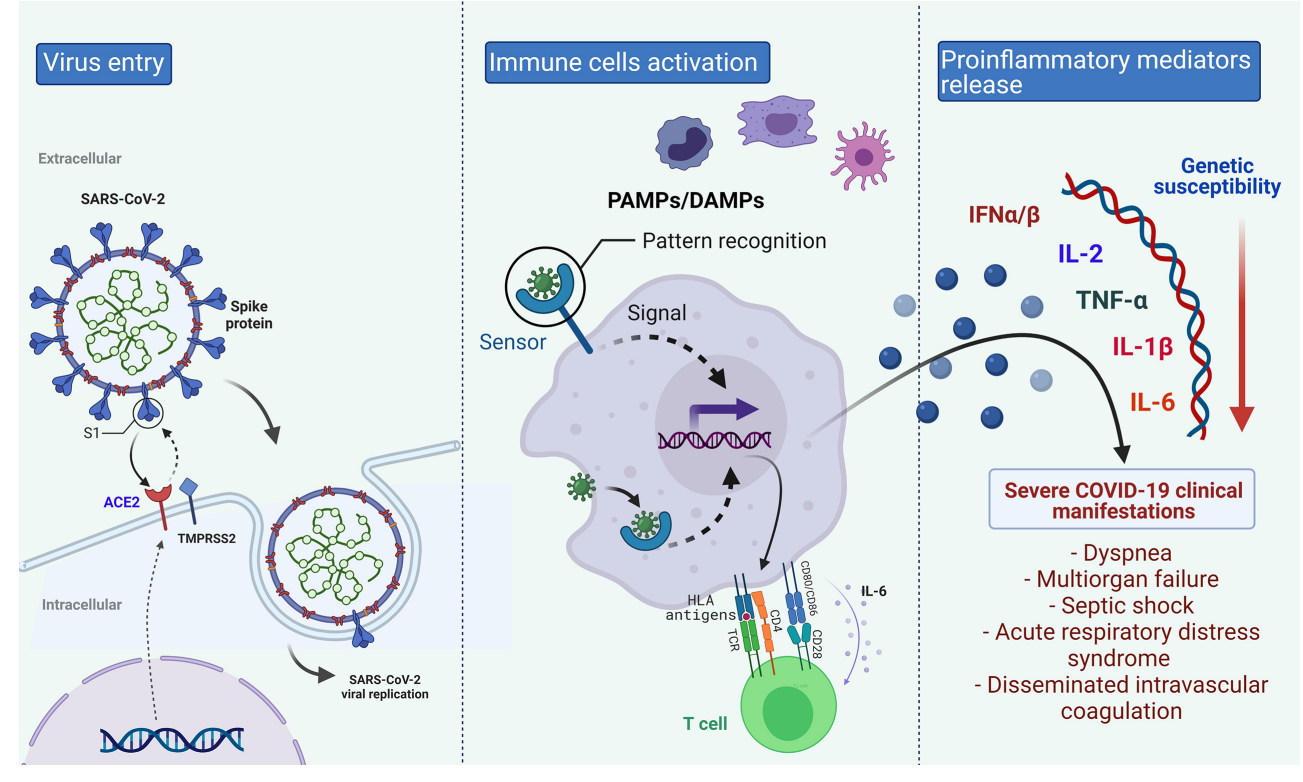

FIGURE 2 | Biological Pathway of COVID-19 in which different genes could be implicated in the disease's differential clinical outcome. Created with BioRender.com. 


\section{GENETIC VARIANTS IN THE STUDY OF COVID-19 SUSCEPTIBILITY AND SEVERITY}

\section{Variants in Genes Related to the Immune System} Human Leukocyte Antigens Gene Complex

The immune system is a complex and effective defense mechanism against pathogens, such as viruses and bacteria, mediated by cells and cytokines involved in the innate and adaptive immune responses (31). Human Leukocyte Antigens (HLA) are proteins encoded by the human MHC genes, which are the most highly polymorphic in the human genome. Individuals display between three and six different HLA alleles that present a variable distribution in the worldwide populations. The resulting HLA molecules' variability affects the cellular immune response to peptides from human infecting-pathogens $(32,33)$. For instance, chronic viral infections can result if CD8+ or CD4+ T cells have difficulty identifying the HLA class I or II antigens on the cell surface or lower expression levels of the HLA molecules (34).

In patients with COVID-19, differences in the immune response of patients with mild and severe forms of the disease have been observed, including IgM and IgG levels (35). Also, a report considered the impact of the variation of the theoretical capacity for binding SARS-CoV-2 peptides to explain the HLA's relation with the clinical heterogeneity of the disease (36). Therefore, this locus variability could explain differential risk susceptibility among populations considering the role of HLA molecules in the modulation of immune response to SARS-CoV2 to identify risk subjects and the design of personalized therapy (37).

One study evaluated the HLA class I and II alleles in 82 Han individuals from Zhejiang with COVID-19. Authors reported that $H L A-C^{\star} 07: 29$ and $-B^{\star} 15: 27$ were found in a higher frequency among patients with COVID-19 than in previous analyzed controls, after correction with the Benjamini-Hochberg method. Other alleles also identified in different frequencies among compared groups, but with uncorrected tests, include $H L A-C^{\star} 07: 29,-C^{\star} 08: 01 G,-B^{\star} 15: 27,-B^{\star} 40: 06,-D R B 1^{\star} 04: 06$, and $-D P B 1^{\star 36: 01}$ alleles, which were found more frequently among patients than in controls; and, $-D R B 1^{\star} 12$ :02 and $-D P B 1^{\star} 04$ :01 alleles, which were less common among individuals with COVID-19 than in the control group (38). In the Italian population, an investigation comprising 99 subjects found associated the $H L A-D R B 1^{\star} 15: 01,-D Q B 1^{\star} 06: 02$, and $-B^{\star} 27: 07$ alleles with COVID-19 susceptibility (39); while an ecological study strongly suggests a permissive role of $H L A-C^{\star} 01$ and $B^{\star} 44$ towards SARS-CoV-2 infection across Italy (40). Meanwhile, the $H L A-A^{\star} 11: 01,-B^{\star} 51: 01$, and $-C^{\star} 14: 02$ alleles were related to the worst outcome among a Chinese population sample (41).

Regarding the severity of the disease, a study including 72 Spaniards with COVID-19 reported three HLA alleles associated with higher mortality $\left(H L A-A^{\star} 11,-C^{\star} 01\right.$, and $\left.-D Q B 1^{\star} 04\right)$ when the scores of Sequential Organ Failure Assessment (SOFA) and
Acute Physiology And Chronic Health Evaluation II (APACHE II) were controlled (42). The $H L A-D R B 1^{\star} 08$ was correlated with mortality of COVID-19 in the Italian population, and the peptide binding prediction analyses showed that the allele was unable to bind any of the SARS-CoV-2 peptides with high affinity (43). The $H L A-C^{\star} 05$ allele was also correlated with COVID-19 mortality in an ecological study (44).

Also, in a recent in silico analysis of the binding affinity between HLA class I molecules and all SARS-CoV-2 peptides, the $H L A-B^{\star} 46: 01$ allele was identified as a vulnerability biomarker due to low predicting binding sites. In contrast, the $H L A-B^{\star} 15: 03$ was considered a protector allele for showing the most significant capacity to present highly conserved SARSCoV-2 peptides. The $H L A-A^{\star} 25: 01$ and $-C^{\star} 01: 02$ alleles were also related to a low predicted capacity for SARS-CoV-2 epitope presentations, whereas the highest predicted presentation capacity was observed for $H L A-A^{\star} 02: 02$ and $-C^{\star} 12: 03$ alleles (45). In agreement, another study using artificial neural networks identified the $H L A-B^{\star} 46: 01$ and $H L A-A^{\star} 25: 01$ as weakly binding alleles, while $H L A-A^{\star} 02: 02$ was one of the $H L A$ class I alleles found to present a strong binding to virus selected peptides (46). Interestingly, $H L A-A^{\star} 02$ alleles, among other class I and II alleles, were also identified as functional molecules for presenting SARS-CoV-2 peptides in a bioinformatic prediction study. In this same last report, an ecological study was also performed, and the $H L A-D R B 1^{\star} 01$ allele was found associated with COVID-19 fatality in a Mexican population; and, although the authors have addressed several limitations, the result must be taken with caution (47).

Nevertheless, other in silico analyses reported a possible association of $H L A-A^{\star} 02: 01$ with increased risk for COVID-19 and a lower capacity of this allele to present SARS-CoV-2 antigens in comparison to other HLA variants (48). These results seem to be contradictory compared to those previously mentioned, in which $H L A-A^{\star} 02$ alleles were considered to have an adequate predicted capacity of antigens presentation. Therefore, the association should be taken with caution until the results of clinical studies were published.

Regarding HLA haplotypes, the study of regional frequencies for the most common Italian haplotypes reported that the HLA$A^{\star} 01: 01-B^{\star} 08: 01-C^{\star} 07: 01-D R B 1^{\star} 03: 01$ and $H L A-A^{\star} 02: 01-$ $B^{\star}$ 18:01- $C^{\star} 07: 01-D R B 1^{\star} 11: 04$ were correlated with COVID-19 incidence and mortality, suggesting risk and protection-related haplotypes, respectively (49). In an association study performed in a Sardinian population, the three-loci haplotype HLA$A^{\star} 30$ :02- $B^{\star} 14$ : $02-C^{\star} 08$ :02 was more common among patients with COVID-19 (50).

Table 1 shows examples of worldwide populations where the mentioned HLA alleles are frequently found. Nevertheless, it is crucial to consider the results of a recent publication in which the relevance of the HLA alleles' homozygosity and heterozygosity was observed. The authors evaluated the synthesis of influenza virus proteins and RNA in lymphocytes from serologically HLAhomozygous or -heterozygous donors after the cells were exposed to the virus. They found that specific HLA-A and HLA-B-homozygous lymphocytes did not synthesize influenza 
TABLE 1 | HLA alleles associated with SARS-CoV-2 infection susceptibility.

\begin{tabular}{|c|c|}
\hline HLA alleles & Populations in which the allele is commonly found ${ }^{a}$ \\
\hline \multicolumn{2}{|l|}{ High-risk } \\
\hline$-A^{*} 25: 01$ & Colombia Arhuaco. \\
\hline$-B^{*} 46: 01$ & $\begin{array}{l}\text { Chinese populations, Hong Kong Chinese, Malaysia Peninsular } \\
\text { Chinese, Singapore Chinese, Taiwan Han Chinese, Thailand } \\
\text { Northeast, USA Chinese, Vietnam Hanoi Kinh. }\end{array}$ \\
\hline$-C^{*} 01: 02$ & $\begin{array}{l}\text { American Samoa, Australian Kimberly Aborigine, Chinese } \\
\text { populations, Colombian populations, Hong Kong Chinese, } \\
\text { Japanese populations, Malaysia Peninsular Chinese, Mexico } \\
\text { Chihuahua Tarahumara, Mexico Hidalgo, Mezquital Valley/Otomi, } \\
\text { Mexico Zapotec, New Caledonia, New Zealand populations, } \\
\text { Papua New Guinea populations, South Korea, Taiwanese } \\
\text { populations, USA Asian, USA Hawaii Okinawa, Venezuela Perja } \\
\text { Mountain Bari, Vietnam Hanoi Kinh, Bolivia/Peru Quechua, Costa } \\
\text { Rica populations. }\end{array}$ \\
\hline \multicolumn{2}{|l|}{ Low-risk } \\
\hline & \\
\hline & \\
\hline & $\begin{array}{l}\text { Azores Terceira Island, German populations, Greece, Italian } \\
\text { populations, Lebanon Mixed, Pakistan Burusho, Papua New } \\
\text { Guinea Wanigela Keapara, Poland, Portugal Azores Terceira } \\
\text { Island, Spain populations, Sudan Mixed, China Jingpo Minority, } \\
\text { Colombian populations. }\end{array}$ \\
\hline \multicolumn{2}{|c|}{ Mortality/severity } \\
\hline & $\begin{array}{l}\text { Myanmar, China, Thailand, Taiwan, Japan, Spain, Mexico, South } \\
\text { Korea, Mongolia, France, United Arab Emirates, Iran. }\end{array}$ \\
\hline$-B^{\star} 51: 01$ & $\begin{array}{l}\text { Italy North, Japan, China, Oman, Armenia, Greece, China, Saudi } \\
\text { Arabia, Switzerland Lugano, United Arab Emirates, Portugal, USA } \\
\text { South Dakota Lakota Sioux and North American Native, Germany, } \\
\text { Croatia, Serbia, Mexico Sonora Seri and Chihuahua, Romania, } \\
\text { China Guizhou Province Miao. }\end{array}$ \\
\hline$-C^{*} 01$ & $\begin{array}{l}\text { China Wuhan, Japan, India Kerala Hindu Pulaya, Brazil Parana } \\
\text { Japanese, Scotland Orkney, Thailand Northeast, South Korea, } \\
\text { Norway Sami, Peru Arequipa Mestizo, Vietnam Hanoi, Mongolia } \\
\text { Oold, Myanmar Mon. }\end{array}$ \\
\hline $\begin{array}{l}-C^{*} 05 \\
-C^{*} 14: 02\end{array}$ & $\begin{array}{l}\text { United Kingdom, England, France, Spain, Wales, Venezuela. } \\
\text { Japan Kyoto and Osaka }\end{array}$ \\
\hline$-D Q B 1^{*} 04$ & $\begin{array}{l}\text { Mexico populations, Norway Sami, Venezuela Zulia Maracaibo } \\
\text { Mixed, Brazil Guarani Nandeva, Papua New Guinea Highland, } \\
\text { Ecuador Amazonia Mixed Ancestry, USA OPTN Hispanic, Russia } \\
\text { Siberia Chukchi, Malaysia Perak Rawa. }\end{array}$ \\
\hline$-D R B 1^{*} 08$ & $\begin{array}{l}\text { Taiwan, Brazil, Mexico, Chile, Sudan, Peru, Burkina Faso, } \\
\text { Argentina, India, Japan, Venezuela, Colombia. }\end{array}$ \\
\hline
\end{tabular}

${ }^{a}$ Representative populations with reported frequencies $>0.10$ are included. Data from Allele Frequency Net Database http://www. allelefrequencies.net/ (51).

virus RNA or protein after virus exposure, suggesting an intrinsic resistance to influenza virus infection in homozygous but not for HLA-heterozygous cells (52).

\section{Cytokine Genes}

The cytokine storm is a complex process that has been difficult to define and delimit. However, it refers to an immune system gone awry and an inflammatory response flaring out of control, which is associated with infectious and noninfectious diseases with a wide variety of consequences in the organism (53). As has been mentioned before, the cytokine storm plays a crucial role in severe COVID-19 cases. SARS-CoV-2 produces the activation of various immune cells (e.g., macrophages, monocytes, dendritic cells), which leads to the secretion of several cytokines, including the pro-inflammatory cytokine IL-6 (54). This cytokine plays a central role in cytokine storm with anti-inflammatory and proinflammatory effects by promoting T-cell proliferation and B-cell differentiation, affecting vascular disease's hormone-like properties, lipid metabolism, insulin resistance, mitochondrial activity, neuroendocrine system, and neuropsychological behavior (55).

High levels of IL- 6 can activate the coagulation pathway and vascular endothelial cells but inhibit the myocardial function (56). In severe COVID-19 patients, an increase of IL-6 levels has been observed and related to the disease's poor prognosis (57). Several gene variants in IL6 (HGNC:6018) with differential cytokine expression and with different disorders have been reported. The rs1800795 (-174C) allele, as well as the promoter variant rs1800796 (-572C), have been associated with higher IL-6 plasma levels (58, $59)$ and with the risk of upper respiratory tract infections (60-62). Moreover, both IL6 variants have been related to the prognosis of different disorders such as sepsis (63), coronary heart disease (64), and diabetes (65). A third variant (rs1800797) on the IL6 promoter reported (66), and its role in studying the genetics of COVID-19 related-cytokine storm can be considered. In addition, seven variants in IL6 (rs140764737, rs142164099, rs2069849, rs142759801, rs190436077, rs148171375, rs13306435) and five variants in IL6R (rs2228144, rs2229237, rs2228145, rs28730735, rs143810642) have been predicted to alter the expression and interaction of IL6 and IL6R which can be implicated in the pathogenesis of COVID-19 and its complications (67).

Genetic variants in the regulatory regions of other cytokines genes have also been reported (68). For instance, nonsynonymous variants affecting the final proteins of TGF- $\beta$ and IFN- $\alpha$, as well as variants modifying the transcriptional activity of TNF- $\alpha$, IL-10, and IL-2, have been described $(68,69)$. Several of these variants have been previously related to infectious disease susceptibility, cytokine storm, and venous thrombosis. Reported variants in cytokines genes associated with those events and their frequencies are shown in Table 2.

In an Iranian population, genotypes of IL1B (HGNC:5992) rs16944 and IL17A (HGNC:5981) rs2275913 were associated with severe influenza $\mathrm{A} / \mathrm{H} 1 \mathrm{~N} 1$ and $\mathrm{B}$ cases, while the frequencies of IL10 (HGNC:5962) rs1800872 and IFNL3 (HGNC:18365) rs8099917 variants were not found different among patients and controls (70). The TNF (HGNC:11892) rs1800629 variant has also been associated with variation in the corresponding cytokine and respiratory infections $(61,62)$.

Regarding the risk of venous thrombosis, 18 single-nucleotide variants in IL1B (HGNC:5992), IL1RN (HGNC:6000), IL1R1 (HGNC:5993), and IL1R2 (HGNC:5994), as well as 25 haplotypes, were evaluated in a case-control study including patients with deep vein thrombosis and controls. Authors found associated the IL1B rs1143633, IL1R1 rs3917332, and IL1RN rs2232354 variants with different risks for venous thrombosis and an increased thrombotic risk for homozygous carriers of the IL1RN haplotype 5 GTGTA (rs3181052/rs419598/rs2232354/ rs315952/rs315949) (72).

The Fc-gamma Receptors (Fc $\gamma \mathrm{R})$ have been implicated in Fcdependent cytokine release stimulation due to human leucocytes' activation to secret various pro-inflammatory cytokines, as 
TABLE 2 | Frequency of allelic variants in cytokine genes associated with infectious disease susceptibility and COVID-19 manifestations.

\begin{tabular}{|c|c|c|c|}
\hline $\begin{array}{l}\text { Cytokine } \\
\text { gene }\end{array}$ & Variants studied & Allele frequency reference ${ }^{a}$ & Ref \\
\hline \multicolumn{4}{|c|}{$\begin{array}{l}\text { Infectious diseases } \\
\text { susceptibility }\end{array}$} \\
\hline $\operatorname{IL1B}$ & $\begin{array}{c}\text { rs16944 } \\
\text { g.4490T>C }\end{array}$ & $\begin{array}{l}\text { European } A=0.3499 \\
\text { African } A=0.5726 \\
\text { East Asian } A=0.4692 \\
\text { South Asian } A=0.6000 \\
\text { American } A=0.5500\end{array}$ & (70) \\
\hline IL17A & $\begin{array}{l}\text { rs2275913 } \\
\text { g.4849G>C }\end{array}$ & $\begin{array}{l}\text { European } \mathrm{G}=0.6203 \\
\text { African } \mathrm{G}=0.9508 \\
\text { East Asian } \mathrm{G}=0.5069 \\
\text { South Asian } \mathrm{G}=0.6200 \\
\text { American } \mathrm{G}=0.7840\end{array}$ & \\
\hline IL6 & $\begin{array}{l}\text { rs1800795 } \\
\text { g.4880C>G }\end{array}$ & $\begin{array}{l}\text { European } \mathrm{C}=0.4155 \\
\text { African } \mathrm{C}=0.0182 \\
\text { East Asian } \mathrm{C}=0.0010 \\
\text { South Asian } \mathrm{C}=0.1390 \\
\text { American } \mathrm{C}=0.1840\end{array}$ & $\begin{array}{c}(60-62, \\
71)\end{array}$ \\
\hline$T N F$ & $\begin{array}{l}\text { rs1800629 } \\
\text { g.4682G>A }\end{array}$ & $\begin{array}{l}\text { European } \mathrm{G}=0.8658 \\
\text { African } \mathrm{G}=0.8805 \\
\text { East Asian } \mathrm{G}=0.9415 \\
\text { South Asian } \mathrm{G}=0.9470 \\
\text { American } \mathrm{G}=0.9310\end{array}$ & $(61,62)$ \\
\hline \multicolumn{4}{|c|}{ Venous thrombosis } \\
\hline $\operatorname{lL1B}$ & $\begin{array}{l}r s 1143633 \\
\text { g.8890G>A }\end{array}$ & $\begin{array}{l}\text { European } \mathrm{C}=0.6660 \\
\text { African } \mathrm{C}=0.8260 \\
\text { East Asian } \mathrm{C}=0.4613 \\
\text { South Asian } \mathrm{C}=0.7480 \\
\text { American } \mathrm{C}=0.7090\end{array}$ & $(72)$ \\
\hline IL1R1 & $\begin{array}{c}\text { rs3917332 } \\
\text { g.102180064A>T }\end{array}$ & $\begin{array}{l}\text { European } A=0.1938 \\
\text { African } A=0.0825 \\
\text { East Asian } A=0.0724 \\
\text { South Asian } A=0.1350 \\
\text { American } A=0.1540\end{array}$ & \\
\hline $\operatorname{ILTRN}$ & $\begin{array}{c}\text { rs2232354 } \\
\text { g.16866T>G }\end{array}$ & $\begin{array}{l}\text { European } T=0.7962 \\
\text { African } T=0.9924 \\
\text { East Asian } T=0.9534 \\
\text { South Asian } T=0.7900 \\
\text { American } T=0.8310\end{array}$ & \\
\hline \multicolumn{4}{|c|}{ Cytokine storm } \\
\hline IL6 & $\begin{array}{l}\text { rs1800797 } \\
\text { g.4456A>G }\end{array}$ & $\begin{array}{l}\text { European } \mathrm{G}=0.9523 \\
\text { African } \mathrm{G}=0.8971 \\
\text { East Asian } \mathrm{G}=0.2093 \\
\text { South Asian } \mathrm{G}=0.6050 \\
\text { American } \mathrm{G}=0.7050 \\
\text { European } \mathrm{A}=0.4076 \\
\text { African } \mathrm{A}=0.0166 \\
\text { East Asian } \mathrm{A}=0.0010 \\
\text { South Asian } \mathrm{A}=0.1340 \\
\text { American } \mathrm{A}=0.1840\end{array}$ & $(58,59)$ \\
\hline FCGR2A & $\begin{array}{l}r s 1801274 \\
g .9541 A>G\end{array}$ & $\begin{array}{l}\text { European } A=0.4891 \\
\text { African } A=0.4743 \\
\text { East Asian } A=0.7222 \\
\text { South Asian } A=0.5810 \\
\text { American } A=0.5490\end{array}$ & (73) \\
\hline
\end{tabular}

${ }^{a}$ Data from 1000 genomes project (74).

GM-CSF, IL-6, and IL-8 (75). The rs1801274 Fc fragment of IgG Receptor IIa (FCGR2A, HGNC:3616) gene was associated with severe pneumonia in patients with $\mathrm{A} / \mathrm{H} 1 \mathrm{~N} 1$ infection. This variant produces a change of histidine to arginine at position 131 of the amino acid sequence. The frequency of homozygous individuals for p.His131 genotype was found to be increased in severe pneumonia patients $(36.6 \%)$ in comparison to household contacts who did not develop respiratory illness (13.2\%). Another gene reported in this study was the RPA Interacting Protein (RPAIN, HGNC:28641) and Complement C1q Binding Protein (C1QBP, HGNC:1243) (73).

Also, several in vivo and in vitro studies of influenza virus infection with lung damage due to cytokine storm have found a strong up-regulation on cytokine gene expressions, such as IL6, IL8 (CXCL8, HGNC:6025), CCL2 (HGNC:10618), CCL5 (HGNC:10632), CXCL9 (HGNC:7098), and CXCL10 (HGNC:10637); as well as a differential expression of inflammasome genes NLRP3 (HGNC:16400) and $I L 1 B$ (HGNC:5992), cytokine genes TNF and IFNB1 (HGNC:5434), and cytokine receptor genes TNFRSF1B (HGNC:11917) and IL4R (HGNC:6015) (53). An investigation found inborn errors of Toll-like receptor 3 (TLR3, HGNC:11849)- and interferon regulatory factor 7 (IRF7, HGNC:6122)-dependent type I IFN immunity related to life-threatening COVID-19 pneumonia. Although the genetic variants were only found in $3.5 \%$ of the studied patients, the results suggested that other IFN variants were probably implicated in the COVID-19 severity and the use of type I IFN as a potential therapeutic strategy in those patients (76). Likewise, a nested case-control study reported that TLR7 (HGNC:15631) deleterious variants were found in $2.1 \%$ of severely affected males and none of the asymptomatic participants, and the corresponding functional gene expression analysis showed a reduction in the TLR7 expression in patients compared with controls suggesting an impairment in type I and II IFN responses (77).

It is worth mentioning that wide inter-ethnic variability in cytokine gene variants' frequencies (IL2, IL6, IL10, TNF, TGFB1, and $I F N G)$ has been reported $(68,78)$. For instance, significant differences in IL2 (HGNC:6001) alleles' distribution among Africans, Caucasians, and Asians have been observed. Meanwhile, high expression alleles of IL6 and IL10 (HGNC:5962) have been more frequently found in Africans, Hispanics, and Asians, than Caucasians. Besides, low expression alleles of IFNG (HGNC:5438) have been more common among Asians than Caucasians (68).

\section{Variants in Coding Genes for Human Receptors of SARS-CoV-2}

SARS-CoV-2 presents a high binding affinity to the ACE2 receptor allowing the virus's entry to the host cell cytosol through acid-dependent proteolytic cleavage of the $S$ protein, with a contribution of the TMPRSS2 and CTSL (21). Besides its role in SARS-CoV-2 infection, ACE2 acts as a negative regulator of the renin-angiotensin system and a facilitator of amino acid transport. The ACE2 system is a critical protective pathway against heart failure with reduced and preserved ejection fraction, including myocardial infarction and hypertension, lung disease, and diabetes mellitus. Unfortunately, the function of ACE2 is lost following the binding of SARS-CoV-2 (79).

Increased ACE2 receptor levels and the two proteases have been associated with identified risk conditions (e.g., increasing 
age, male gender, and smoking) of COVID-19 susceptibility and clinical outcome (21). Also, genetic variants of ACE2 (HGNC:13557) that alter its transcriptional activity have been described (e.g., rs2285666, c.439+4G>A) $(80,81)$. An early study found higher allele frequencies of variants (e.g., rs143695310) associated with elevated expression of ACE2 among East Asian populations, which may suggest a higher susceptibility to COVID-19 individuals from this region (82). A recent investigation has reported that genetic determinants of the highest expression of ACE2 can be observed in South Asian and East Asian populations, while the lowest expression levels of ACE2 were observed for Africans (83). Likewise, a genetic predisposition for the lowest TMPRSS2 (HGNC:11876) expression levels was observed for Africans and the highest for East Asians. Moreover, significant differences in TMPRSS2 expression levels among males and females were reported in the study (83).

Besides, variants with potential impact on the receptor stability have been reported. For instance, three common missense changes in ACE2 (p.Asn720Asp, p.Lys26Arg, and p.Gly211Arg) were predicted to interfere with protein structure and stabilization, while other two variants (p.Leu351Val and p.Pro389His) has been predicted to interfere with SARS-CoV-2 spike protein binding (84). Likewise, a study using web-based tools reported several variants in genes that encode proteins related to the SARS-CoV-2 entry into the host cells: the already mentioned ACE2 and TMPRSS2, as well as TMPRSS11A (HGNC:27954), ELANE (HGNC:3309), and CTSL (HGNC:2537). The authors found 48 variants in these genes with possible functional consequences, and some of them were reported to be shared among specific populations (85).

Nevertheless, the association results of the receptor variants with COVID-19 susceptibility remain controversial. For instance, Hou et al. found associated ACE2 variants, such as p.Arg514Gly, in the African/African-American populations with cardiovascular and pulmonary conditions due to the alteration of the angiotensinogen-ACE2 interactions. Additionally, the authors identified variants in TMPRSS2 (e.g., p.Val160Met, rs12329760) that could explain the COVID-19 susceptibility and some complication risk factors such as cancer and male gender (86). Meanwhile, a study with multi-scale modeling approaches in combination with sequence and phylogenetic analysis evaluated eight relevant variants located at the interaction surface of ACE2 (i.e., rs961360700, rs143936283, rs146676783, rs759579097, rs370610075, rs766996587, rs73635825, and rs781255386). These SNPs are rare variants, except for European (non-Finnish) and African populations, and none of them would disrupt this receptor's interaction with SARS-CoV-2 proteins (87).

Finally, the implication of an ACE1 (HGNC:2707) deletion/ insertion (D/I, intron 16) variant in the ACE2 expression and the COVID-19 clinical course was also proposed at the early stages of the pandemic (88). Nevertheless, later studies have reported that this variant could be related to the COVID-19 severity, but only if the patients' hypertension status is considered $(89,90)$.

\section{Variants in Other Genes Related to COVID-19 Susceptibility and Severity}

In addition to immune and SARS-CoV-2 receptors' genes, variants in genes coding other proteins related to susceptibility and severity of COVID-19 have been identified. Recently, two independent genome-wide association studies (GWAS) had been performed among European populations (Italian and Spanish) (91) and individuals from the United States and the United Kingdom (92). In both cases, an association of loci 3p21.31 and 9q34.2 with COVID-19 severity were identified. The first study by Ellinghaus et al. reported the associations of LZTFL1 (HGNC:6741) rs11385942, at locus 3p21.31, and $A B O$ (HGNC:79) rs657152, at locus 9q34.2, with genetic susceptibility to COVID-19 (91). Meanwhile, Shelton et al. identified several non-genetic conditions as risk factors for hospitalization, and the genetic variants LZTFL1 rs13078854 and $A B O$ rs9411378 were associated with COVID-19 outcome severity and diagnostic, respectively (92). LZTFL1 encodes the ubiquitously expressed protein leucine zipper transcription factor-like 1, and it is strongly expressed in human lung cells (91). Nevertheless, none of the publications can explain this gene's role in the susceptibility or severity of COVID-19, but there are several genes nearby in the $3 p 21.31$ locus that could plausibly be driving the association, including SLC6A20 (HGNC:30927), CCR9 (HGNC:1610), FYCO1 (HGNC:14673), CXCR6 (HGNC:16647), and XCR1 (HGNC:1625) (92).

The role of $A B O$ in COVID-19 susceptibility and clinical manifestations has been reported in genetic and non-genetic studies. Previous reports (93-95) and GWAS $(91,92)$ have observed a higher risk of COVID-19 infection among individuals with $\mathrm{A}$ group than other blood groups and a lower susceptibility for the $\mathrm{O}$ group. $\mathrm{ABO}$ blood group has been previously associated with infection susceptibility of other diseases such as influenza, malaria, schistosomiasis, and SARS$\mathrm{CoV}$. The hypotheses that blood groups can serve as receptors and/or co-receptors for bacteria, viruses, and parasites and that those blood antigens contribute to intracellular uptake, signal transduction, or adhesion have been stated (96). Besides, the idea that natural antibodies related to blood groups could contribute to the virus's innate immune response has been proposed. Nevertheless, the $\mathrm{ABO}$ groups' precise role in the SARS-CoV-2 infection mechanism still needs to be demonstrated (92).

Wang et al. also performed a GWAS among 332 Chinese patients and pedigree analysis. The authors reported the association with COVID-19 severity of the gene locus located in TMEM189 (PEDS1, HGNC:16735)-UBE2V1 (HGNC:12494), which is involved in the IL-1 signaling pathway. In the pedigree analysis, a potential monogenic effect of loss of function variants in GOLGA3 (HGNC:4426) and DPP7 (HGNC:14892) was suggested when authors looked for rare variants in families where a differential clinical outcome was observed among siblings (41). One more GWAS performed in 2,244 critically ill patients with COVID-19 from intensive care units in the United Kingdom found significant associations in several loci: in a gene cluster that encodes antiviral restriction enzyme activators OAS1 (HGNC:8086), OAS2 (HGNC:8087), and OAS3 (HGNC:8088); 
near the gene that encodes tyrosine kinase 2 (TYK2, HGNC:12440); within the gene that encodes dipeptidyl peptidase 9 (DPP9, HGNC:18648); and in the interferon receptor gene IFNAR2 (HGNC:5433) (97).

Patients with critical COVID-19 can present venous thromboembolism and/or systemic coagulopathies such as Disseminated Intravascular Coagulation (DIC) (13). This complication is characterized by the combined occurrence of activation of the extrinsic coagulation pathway and decreased activity of the protein C-protein S and Antithrombin (AT) inhibitory pathways, and it can be presented with excessive or inhibited fibrinolysis (98). DIC's clinical and laboratory characteristics in COVID-19 are different from the typical presentation of these conditions, and a timely diagnosis is required to avoid the deterioration of pulmonary oxygen exchange (13). In this sense, a genetic marker that could predict coagulation complications could help to start appropriate treatment. For instance, the involvement of Mannose-Binding Lectin (MBL) and MBL-associated serine protease (MASP)-1/3 in coagulation has been reported, and its deficiency has been considered as a risk factor for DIC during sepsis complication; therefore, genetic variants producing a decrease of these proteins or their activity could be positively related with coagulopathies secondary to COVID-19 (99).

Besides, other genes with risk variants for DIC have been identified. In the anticoagulant pathways, variants in protein $\mathrm{C}$ gene (PROC, HGNC:9451), factor V Leiden (F5, HGNC:3542), and deficiencies of AT (SERPINC1, HGNC:775) have been related to an impaired function of the coagulation. While variants in the serpin plasminogen activator inhibitor 1 (SERPINE1, HGNC:8583) could impact the encoded protein levels, which is considered one of the main inhibitors of fibrinolysis, and it is related to DIC development. Additionally, variants in fibrinogen genes that promote the pro-coagulant pathways leading to microvascular thrombi formation in various organs have been described (98).

\section{DISCUSSION}

The present review provides an overview of different genes implicated or related to the susceptibility or severity of COVID19. Nevertheless, with the information available to date, not everything has been resolved about the genetic involvement in COVID-19 susceptibility or severity, and new knowledge in the field has been continuously generated. Moreover, several consortia are dedicated to assessing the genetic determinants of COVID-19 in the worldwide population (30).

The COVID-19 presents a wide variability of clinical manifestations, from asymptomatic individuals to critical patients with fatal outcomes. Therefore the phenotype characterization probably represents the biggest challenge in COVID-19 genetic association studies of susceptibility and/or severity; mainly, to accomplish that selected subjects as controls had not presented the asymptomatic form of the disease. According to the reported studies, the comparison groups, co-variables adjustment, non-genetic factors, and asymptomatic individuals have great relevance in the association studies of genetic variants with COVID-19 susceptibility and clinical outcome.

Several HLA alleles have been associated with COVID-19 susceptibility and severity through various methodologies and in specific populations. In some cases, the HLA allele found related to the disease is shared between populations. For instance, the $H L A-A^{\star} 11$ was reported in the investigations, including a sample of Chinese and Spanish populations, but it was not associated with Italian patients. Therefore, the interethnic variability in the $H L A$ allele frequencies should be taken into account to identify the COVID-19 genetic marker. Moreover, the impact of SARSCoV-2 genome variants in the host alleles associated must be assessed since the efficiency of antigens presentation by HLA molecules would be different according to the sites of the virus mutations $(100,101)$.

Current evidence highlights the relevance of cytokine storm in COVID-19 severity and several complications, including a fatal outcome. Genetic and non-genetic factors could explain the uncontrolled inflammatory response; therefore, the study of cytokine genes with adequate co-variables adjustment could lead to the identification of genetic markers related to COVID19 outcome and the design and/or selection of personalized therapy. The cytokine storm's early control is crucial to improving COVID-19 patients' evolution (102).

According to ACE2 and TMPRSS2 variants, the African populations could have a lower susceptibility to COVID-19 than East and South Asians. Nevertheless, variants in both genes have not provided the genetic information regarding COVID-19 susceptibility as was expected. The 3p21.31 chromosome region and variants in the $A B O$ gene recently identified in two different GWAS including diverse populations have been a relevant finding in the genetic study of COVID-19; however, further studies enlightening the role of the proteins encoded by the identified genes in the COVID-19 and their association in other populations is still warranted. Information about the penetrance of the risk alleles is required, and the inclusion of miRNAs in these studies could complement the genetic studies of COVID-19 susceptibility and its severity (103).

Herein we have presented several genetic variants reported to be associated with COVID-19 susceptibility and/or severity and others implicated in the biological pathway of the disease, considered relevant to include in subsequent clinical studies. Identifying genetic markers associated with the susceptibility or clinical outcome of COVID-19 could provide an essential contribution to the knowledge of this disease for the detection of susceptible individuals or populations and the design of therapeutic strategies (i.e., vaccine and pharmacologic treatment).

\section{AUTHOR CONTRIBUTIONS}

IF-G and RF-V contributed to the manuscript's design, the figures production, and the writing of the manuscript. All authors contributed to the article and approved the submitted version. 


\section{FUNDING}

IF-G was supported by a Posdoctoral fellowship by the Consejo Nacional de Ciencia y Tecnología ESTANCIAS POSDOCTORALES POR

\section{REFERENCES}

1. WHO. WHO Coronavirus Disease (COVID-19) Dashboard. Available at: https://covid19.who.int/ (Accessed on Jul 30, 2020).

2. Baj J, Karakuła-Juchnowicz H, Teresiński G, Buszewicz G, Ciesielka M, Sitarz E, et al. COVID-19: Specific and Non-Specific Clinical Manifestations and Symptoms: The Current State of Knowledge. J Clin Med (2020) 5 (9):1753. doi: $10.3390 / \mathrm{jcm} 9061753$

3. World Health Organization Clinical management of COVID-19. Interim guidance. Available at: https://www.who.int/publications/i/item/clinicalmanagement-of-covid-19 (Accessed on Aug 6, 2020).

4. Driggin E, Madhavan MV, Bikdeli B, Chuich T, Laracy J, Biondi-Zoccai G, et al. Cardiovascular Considerations for Patients, Health Care Workers, and Health Systems During the COVID-19 Pandemic. J Am Coll Cardiol (2020) 75:2352-71. doi: 10.1016/j.jacc.2020.03.031

5. Mehta P, McAuley DF, Brown M, Sanchez E, Tattersall RS, Manson JJ. COVID-19: consider cytokine storm syndromes and immunosuppression. Lancet (2020) 395:1033-4. doi: 10.1016/S0140-6736(20)30628-0

6. Terpos E, Ntanasis-Stathopoulos I, Elalamy I, Kastritis E, Sergentanis TN, Politou M, et al. Hematological findings and complications of COVID-19. Am J Hematol (2020) 95:834-47. doi: 10.1002/ajh.25829

7. Vincent JL, Taccone FS. Understanding pathways to death in patients with COVID-19. Lancet Respir Med (2020) 8:430-2. doi: 10.1016/S2213-2600(20) 30165-X

8. Du Y, Tu L, Zhu P, Mu M, Wang R, Yang P, et al. Clinical features of 85 fatal cases of COVID-19 from Wuhan: A retrospective observational study. Am J Respir Crit Care Med (2020) 201:1372-9. doi: 10.1164/rccm.2020030543OC

9. Siordia JA. Epidemiology and clinical features of COVID-19: A review of current literature. J Clin Virol (2020) 127:104357. doi: 10.1016/ j.jcv.2020.104357

10. Wu C, Chen X, Cai Y, Xia J, Zhou X, Xu S, et al. Risk Factors Associated With Acute Respiratory Distress Syndrome and Death in Patients With Coronavirus Disease 2019 Pneumonia in Wuhan, China. JAMA Intern Med (2020) 180:934. doi: 10.1001/jamainternmed.2020.0994

11. Ruan Q, Yang K, Wang W, Jiang L, Song J. Clinical predictors of mortality due to COVID-19 based on an analysis of data of 150 patients from Wuhan, China. Intensive Care Med (2020) 46:846-8. doi: 10.1007/s00134020-05991-X

12. Zheng YY, Ma YT, Zhang JY, Xie X. COVID-19 and the cardiovascular system. Nat Rev Cardiol (2020) 17:259-60. doi: 10.1038/s41569-020-0360-5

13. Levi M, Thachil J. Coronavirus Disease 2019 Coagulopathy: Disseminated Intravascular Coagulation and Thrombotic Microangiopathy-Either, Neither, or Both. Semin Thromb Hemost (2020) 46:781-4. doi: 10.1055/s0040-1712156

14. Liu X, Zhou H, Zhou Y, Wu X, Zhao Y, Lu Y, et al. Risk factors associated with disease severity and length of hospital stay in COVID-19 patients. J Infect (2020) 81:e95. doi: 10.1016/j.jinf.2020.04.008

15. Park J-H, Jang W, Kim S-W, Lee J, Lim Y-S, Cho C-G, et al. The Clinical Manifestations and Chest Computed Tomography Findings of Coronavirus Disease 2019 (COVID-19) Patients in China: A Proportion Meta-Analysis. Clin Exp Otorhinolaryngol (2020) 13:95-105. doi: 10.21053/ceo.2020.00570

16. Lechien JR, Chiesa-Estomba CM, De Siati DR, Horoi M, Le Bon SD, Rodriguez A, et al. Olfactory and gustatory dysfunctions as a clinical presentation of mild-to-moderate forms of the coronavirus disease (COVID-19): as multicenter European study. Eur Arch Otorhinolaryngol (2020) 277:2251-61. doi: 10.1007/s00405-020-05965-1

17. Yan CH, Faraji F, Prajapati DP, Boone CE, DeConde AS. Association of chemosensory dysfunction and COVID-19 in patients presenting with influenza-like symptoms. Int Forum Allergy Rhinol (2020) 10:806-13. doi: $10.1002 /$ alr.22579
MÉXICO EN ATENCIÓN A LA CONTINGENCIA DEL COVID-

19. The allocated budget supports this work to research (RFV-HLA Laboratory, protocol number C53-20) from the Instituto Nacional de Enfermedades Respiratorias Ismael Cosio Villegas (INER).

18. Mao L, Jin H, Wang M, Hu Y, Chen S, He Q, et al. Neurologic Manifestations of Hospitalized Patients with Coronavirus Disease 2019 in Wuhan, China. JAMA Neurol (2020) 77:683-90. doi: 10.1001/ jamaneurol.2020.1127

19. Varga Z, Flammer AJ, Steiger P, Haberecker M, Andermatt R, Zinkernagel AS, et al. Endothelial cell infection and endotheliitis in COVID-19. Lancet (2020) 395:1417-8. doi: 10.1016/S0140-6736(20)30937-5

20. Millet JK, Whittaker GR. Host cell proteases: Critical determinants of coronavirus tropism and pathogenesis. Virus Res (2015) 202:120-34. doi: 10.1016/j.virusres.2014.11.021

21. Muus C, Luecken M, Eraslan G, Waghray A, Heimberg G, Sikkema L, et al. Integrated analyses of single-cell atlases reveal age, gender, and smoking status associations with cell type-specific expression of mediators of SARSCoV-2 viral entry and highlights inflammatory programs in putative target cells. bioRxiv (2020). doi: 10.1101/2020.04.19.049254

22. Ahmed-Hassan H, Sisson B, Shukla RK, Wijewantha Y, Funderburg NT, Li Z, et al. Innate Immune Responses to Highly Pathogenic Coronaviruses and Other Significant Respiratory Viral Infections. Front Immunol (2020) 11:1979. doi: 10.3389/FIMMU.2020.01979

23. Freeman TL, Swartz TH. Targeting the NLRP3 Inflammasome in Severe COVID-19. Front Immunol (2020) 11:1518. doi: 10.3389/fimmu.2020.01518

24. Henry BM. COVID-19, ECMO, and lymphopenia: a word of caution. Lancet Respir Med (2020) 8:e24. doi: 10.1016/S2213-2600(20)30119-3

25. Azkur AK, Akdis M, Azkur D, Sokolowska M, Veen W, Brüggen M, et al. Immune response to SARS-CoV-2 and mechanisms of immunopathological changes in COVID-19. Allergy (2020) 75:1564-81. doi: 10.1111/all.14364

26. Conti P, Ronconi G, Caraffa A, Gallenga C, Ross R, Frydas I, et al. Induction of pro-inflammatory cytokines (IL-1 and IL-6) and lung inflammation by Coronavirus-19 (CoV-19 or SARS-CoV-2): anti-inflammatory strategies. Biolife - Scientific Publisher. J Biol Regul Homeost Agents (2020) 34:327-31. doi: 10.23812/CONTI-E

27. Tay MZ, Poh CM, Rénia L, MacAry PA, Ng LFP. The trinity of COVID-19: immunity, inflammation and intervention. Nat Rev Immunol (2020) 20:36374. doi: 10.1038/s41577-020-0311-8

28. Huang C, Wang Y, Li X, Ren L, Zhao J, Hu Y, et al. Clinical features of patients infected with 2019 novel coronavirus in Wuhan, China. Lancet (2020) 395:497-506. doi: 10.1016/S0140-6736(20)30183-5

29. Kumar S, Nyodu R, Maurya VK, Saxena SK. Host Immune Response and Immunobiology of Human SARS-CoV-2 Infection. In: Saxena S, editors. Coronavirus Disease 2019 (COVID-19). Medical Virology: From Pathogenesis to Disease Control. Singapore: Springer (2020). p.43-53. doi: 10.1007/978981-15-4814-7_5

30. Di Maria E, Latini A, Borgiani P, Novelli G. Genetic variants of the human host influencing the coronavirus-associated phenotypes (SARS, MERS and COVID-19): rapid systematic review and field synopsis. Hum Genomics (2020) 14:30. doi: 10.1186/s40246-020-00280-6

31. Thompson AE. The immune system. JAMA - J Am Med Assoc (2015) 313:1686. doi: 10.1001/jama.2015.2940

32. Zahn LM. HLA genetics and COVID-19. Sci (80- ) (2020) 368:841.2-841. doi: 10.1126/science.368.6493.841-b

33. Iwasaki A, Grubaugh ND. Why does Japan have so few cases of COVID-19? EMBO Mol Med (2020) 12:e12481. doi: 10.15252/emmm.202012481

34. Gao J, Zhu C, Zhu Z, Tang L, Liu L, Wen L, et al. The human leukocyte antigen and genetic susceptibility in human diseases. J Bio-X Res (2019) 2:112-20. doi: 10.1097/jbr.0000000000000044

35. Ovsyannikova IG, Haralambieva IH, Crooke SN, Poland GA, Kennedy RB. The role of host genetics in the immune response to SARS-CoV-2 and COVID-19 susceptibility and severity. Immunol Rev (2020) 296:205-19. doi: 10.1111/imr.12897

36. Iturrieta-Zuazo I, Rita CG, García-Soidán A, de Malet Pintos-Fonseca A, Alonso-Alarcón N, Pariente-Rodríguez R, et al. Possible role of HLA class-I 
genotype in SARS-CoV-2 infection and progression: A pilot study in a cohort of Covid-19 Spanish patients. Clin Immunol (2020) 219:108572. doi: 10.1016/j.clim.2020.108572

37. Tavasolian F, Rashidi M, Reza Hatam G, Jeddi M, Zavaran Hosseini A, Hussain Mosawi S, et al. Immune Response, and Susceptibility to COVID19. Front Immunol (2021) 11:601886. doi: 10.3389/fimmu.2020.601886

38. Wang W, Zhang W, Zhang J, He J, Zhu F. Distribution of HLA allele frequencies in 82 Chinese individuals with coronavirus disease-2019 (COVID-19). HLA (2020) 96:194-6. doi: 10.1111/tan.13941

39. Novelli A, Andreani M, Biancolella M, Liberatoscioli L, Passarelli C, Colona VL, et al. HLA allele frequencies and susceptibility to COVID-19 in a group of 99 Italian patients. HLA (2020) 96:610-4. doi: 10.1111/ $\tan .14047$

40. Correale P, Mutti L, Pentimalli F, Baglio G, Saladino RE, Sileri P, et al. HLA$B * 44$ and $C * 01$ Prevalence Correlates with Covid 19 Spreading across Italy. Int J Mol Sci (2020) 21:5205. doi: 10.3390/ijms21155205

41. Wang F, Huang S, Gao R, Zhou Y, Lai C, Li Z, et al. Initial whole-genome sequencing and analysis of the host genetic contribution to COVID-19 severity and susceptibility. Cell Discovery (2020) 6:83. doi: 10.1038/s41421020-00231-4

42. Lorente L, Martín MM, Franco A, Barrios Y, Cáceres JJ, Solé-Violán J, et al. HLA genetic polymorphisms and prognosis of patients with COVID-19. Med Intensiva (2020) 45:96. doi: 10.1016/j.medin.2020.08.004

43. Amoroso A, Magistroni P, Vespasiano F, Bella A, Bellino S, Puoti F, et al. HLA and ABO Polymorphisms May Influence SARS-CoV-2 Infection and COVID-19 Severity. Transplantation (2021) 105:193-200. doi: 10.1097/ TP. 0000000000003507

44. Sakuraba A, Haider H, Sato T. Population Difference in Allele Frequency of HLA-C ${ }^{\star} 05$ and Its Correlation with COVID-19 Mortality. Viruses (2020) 12:1333. doi: $10.3390 / \mathrm{v} 12111333$

45. Nguyen A, David JK, Maden SK, Wood MA, Weeder BR, Nellore A, et al. Human Leukocyte Antigen Susceptibility Map for Severe Acute Respiratory Syndrome Coronavirus 2. J Virol (2020) 94:e00510-20. doi: 10.1128/ jvi.00510-20

46. La Porta CAM, Zapperi S. Estimating the Binding of Sars-CoV-2 Peptides to HLA Class I in Human Subpopulations Using Artificial Neural Networks. Cell Syst (2020) 11:412-7.e2. doi: 10.1016/j.cels.2020.08.011

47. Romero-López J, Carnalla-Cortés M, Pacheco-Olvera D, Ocampo-Godínez J, Oliva-Ramírez J, Moreno-Manjón J, et al. A bioinformatic prediction of antigen presentation from SARS-CoV-2 spike protein revealed a theorical correlation of HLA-DRB1*01 with COVID-19 fatality in Mexican population: an ecological approach. J Med Virol (2020) 93:2029-38. doi: 10.1002/jmv.26561

48. Tomita Y, Ikeda T, Sato R, Sakagami T. Association between HLA gene polymorphisms and mortality of COVID-19: An in silico analysis. Immun Inflamm Dis (2020) 8:684-94. doi: 10.1002/iid3.358

49. Pisanti S, Deelen J, Gallina AM, Caputo M, Citro M, Abate M, et al. Correlation of the two most frequent HLA haplotypes in the Italian population to the differential regional incidence of Covid - 19. J Transl Med (2020) 18:352. doi: 10.1186/s12967-020-02515-5

50. Littera R, Campagna M, Deidda S, Angioni G, Cipri S, Melis M, et al. Human Leukocyte Antigen Complex and Other Immunogenetic and Clinical Factors Influence Susceptibility or Protection to SARS-CoV-2 Infection and Severity of the Disease Course. The Sardinian Experience. Front Immunol (2020) 11:605688. doi: 10.3389/fimmu.2020.605688

51. Gonzalez-Galarza FF, McCabe A, Dos Santos EJM, Jones J, Takeshita L, Ortega-Rivera ND, et al. Allele frequency net database (AFND) 2020 update: Gold-standard data classification, open access genotype data and new query tools. Nucleic Acids Res (2020) 48:D783-8. doi: 10.1093/nar/gkz1029

52. Ochoa EE, Huda R, Scheibel SF, Nichols JE, Mock DJ, El-Daher N, et al. HLA-associated protection of lymphocytes during influenza virus infection. Virol J (2020) 17:128. doi: 10.1186/s12985-020-01406-x

53. Tisoncik JR, Korth MJ, Simmons CP, Farrar J, Martin TR, Katze MG. Into the Eye of the Cytokine Storm. Microbiol Mol Biol Rev (2012) 76:16-32. doi: $10.1128 / \mathrm{mmbr} .05015-11$

54. Chakraborty C, Sharma AR, Bhattacharya M, Sharma G, Lee S, Agoramoorthy G. COVID-19: Consider IL-6 receptor antagonist for the therapy of cytokine storm syndrome in SARS-CoV-2 infected patients. J Med Virol (2020) 92(11):2260-62. doi: 10.1002/jmv.26078
55. Zhang C, Wu Z, Li J-W, Zhao H, Wang G-Q. Cytokine release syndrome in severe COVID-19: interleukin-6 receptor antagonist tocilizumab may be the key to reduce mortality. Int J Antimicrob Agents (2020) 55:105954. doi: 10.1016/J.IJANTIMICAG.2020.105954

56. Tanaka T, Narazaki M, Kishimoto T. Immunotherapeutic implications of IL-6 blockade for cytokine storm. Immunotherapy (2016) 8:959-70. doi: 10.2217/imt-2016-0020

57. Chen X, Zhao B, Qu Y, Chen Y, Xiong J, Feng Y, et al. Detectable serum SARS-CoV-2 viral load (RNAaemia) is closely associated with drastically elevated interleukin 6 (IL-6) level in critically ill COVID-19 patients. medRxiv (2020) 71:1937-42. doi: 10.1101/2020.02.29.20029520

58. Sanderson SC, Kumari M, Brunner EJ, Miller MA, Rumley A, Lowe GD, et al. Association between IL6 gene variants $-174 \mathrm{G}>\mathrm{C}$ and $-572 \mathrm{G}>\mathrm{C}$ and serum IL-6 levels: Interactions with social position in the Whitehall II cohort. Atherosclerosis (2009) 204:459-64. doi: 10.1016/j.atherosclerosis.2008.09.019

59. Brull DJ, Montgomery HE, Sanders J, Dhamrait S, Luong L, Rumley A, et al. Interleukin-6 gene $-174 \mathrm{G}>\mathrm{C}$ and $-572 \mathrm{G}>\mathrm{C}$ promoter polymorphisms are strong predictors of plasma interleukin- 6 levels after coronary artery bypass surgery. Arterioscler Thromb Vasc Biol (2001) 21:1458-63. doi: 10.1161/ hq0901.094280

60. Doyle WJ, Casselbrant ML, Li-Korotky HS, Cullen Doyle AP, Lo CY, Turner $\mathrm{R}$, et al. The interleukin 6-174 C/C genotype predicts greater rhinovirus illness. J Infect Dis (2010) 201:199-206. doi: 10.1086/649559

61. Patel JA, Nair S, Revai K, Grady J, Saeed K, Matalon R, et al. Association of proinflammatory cytokine gene polymorphisms with susceptibility to otitis media. Pediatrics (2006) 118:2273-9. doi: 10.1542/peds.2006-0764

62. Revai K, Patel JA, Grady JJ, Nair S, Matalon R, Chonmaitree T. Association between cytokine gene polymorphisms and risk for upper respiratory tract infection and acute otitis media. Clin Infect Dis (2009) 49:257-61. doi: $10.1086 / 599833$

63. Michalek J, Svetlikova P, Fedora M, Klimovic M, Klapacova L, Bartosova D, et al. Interleukin-6 gene variants and the risk of sepsis development in children. Hum Immunol (2007) 68:756-60. doi: 10.1016/j.humimm.2007.06.003

64. Humphries SE, Luong LA, Ogg MS, Hawe E, Miller GJ. The interleukin-6 $174 \mathrm{G} / \mathrm{C}$ promoter polymorphism is associated with risk of coronary heart disease and systolic blood pressure in healthy men. Eur Heart J (2001) 22:2243-52. doi: 10.1053/euhj.2001.2678

65. Eze IC, Imboden M, Kumar A, Adam M, von Eckardstein A, Stolz D, et al. A common functional variant on the pro-inflammatory Interleukin- 6 gene may modify the association between long-term PM10 exposure and diabetes. Environ Heal (2016) 15:39. doi: 10.1186/s12940-016-0120-5

66. Terry CF, Loukaci V, Green FR. Cooperative influence of genetic polymorphisms on interleukin 6 transcriptional regulation. J Biol Chem (2000) 275:18138-44. doi: 10.1074/jbc.M000379200

67. Strafella C, Caputo V, Termine A, Barati S, Caltagirone C, Giardina E, et al. Investigation of genetic variations of IL6 and IL6r as potential prognostic and pharmacogenetics biomarkers: Implications for covid-19 and neuroinflammatory disorders. Life (2020) 10:1-10. doi: 10.3390/ life10120351

68. Hoffmann SC, Stanley EM, Cox ED, DiMercurio BS, Koziol DE, Harlan DM, et al. Ethnicity greatly influences cytokine gene polymorphism distribution. Am J Transpl (2002) 2:560-7. doi: 10.1034/j.1600-6143.2002.20611.x

69. Sankaran D, Asderakis A, Ashraf S, Roberts ISD, Short CD, Dyer PA, et al. Cytokine gene polymorphisms predict acute graft rejection following renal transplantation. Kidney Int (1999) 56:281-8. doi: 10.1046/j.15231755.1999.00536.x

70. Keshavarz M, Namdari H, Farahmand M, Mehrbod P, Mokhtari-Azad T, Rezaei F. Association of polymorphisms in inflammatory cytokines encoding genes with severe cases of influenza $\mathrm{A} / \mathrm{H} 1 \mathrm{~N} 1$ and $\mathrm{B}$ in an Iranian population. Virol J (2019) 16:79. doi: 10.1186/s12985-019-1187-8

71. Zehsaz F, Farhangi N, Monfaredan A. Interleukin-6 G-174C gene polymorphism and susceptibility to upper respiratory tract infection among endurance athletes. J Exerc Sci Fit (2014) 12:15-9. doi: 10.1016/ j.jesf.2013.12.002

72. Van Minkelen R, De Visser MCH, Houwing-Duistermaat JJ, Vos HL, Bertina RM, Rosendaal FR. Haplotypes of IL1B, IL1RN, IL1R1, and IL1R2 and the risk of venous thrombosis. Arterioscler Thromb Vasc Biol (2007) 27:1486-91. doi: 10.1161/ATVBAHA.107.140384 
73. Zúñiga J, Buendía-Roldán I, Zhao Y, Jiménez L, Torres D, Romo J, et al. Genetic variants associated with severe pneumonia in $\mathrm{A} / \mathrm{H} 1 \mathrm{~N} 1$ influenza infection. Eur Respir J (2012) 39:604-10. doi: 10.1183/09031936.00020611

74. Auton A, Abecasis GR, Altshuler DM, Durbin RM, Bentley DR, Chakravarti A, et al. A global reference for human genetic variation. Nature (2015) 526:68-74. doi: 10.1038/nature15393

75. Dettke M, Loibner H. Different types of FC gamma-receptors are involved in anti-Lewis Y antibody induced effector functions in vitro. Br J Cancer (2000) 82:441-5. doi: 10.1054/bjoc.1999.0940

76. Zhang Q, Liu Z, Moncada-Velez M, Chen J, Ogishi M, Bigio B, et al. Inborn errors of type I IFN immunity in patients with life-threatening COVID-19. Science (2020) 370:eabd4570. doi: 10.1126/science.abd4570

77. Fallerini C, Daga S, Mantovani S, Benetti E, Picchiotti N, Francisci D, et al. Association of Toll-like receptor 7 variants with life-threatening COVID-19 disease in males: findings from a nested case-control study. Elife (2021) 10: e67569. doi: 10.7554/eLife.67569

78. Manchanda PK, Kumar A, Bid HK, Mittal RD. Interleukin-1 $\beta$ and receptor antagonist (IL-1Ra) gene polymorphisms and the prediction of the risk of end-stage renal disease. Biomarkers (2006) 11:164-73. doi: 10.1080/ 13547500500525383

79. Gheblawi M, Wang K, Viveiros A, Nguyen Q, Zhong JC, Turner AJ, et al. Angiotensin-Converting Enzyme 2: SARS-CoV-2 Receptor and Regulator of the Renin-Angiotensin System: Celebrating the 20th Anniversary of the Discovery of ACE2. Circ Res (2020) 126:1456-74. doi: 10.1161/ CIRCRESAHA.120.317015

80. Debnath M, Banerjee M, Berk M. Genetic gateways to COVID-19 infection: Implications for risk, severity, and outcomes. FASEB J (2020) 34:8787-95. doi: 10.1096/fj.202001115R

81. Asselta R, Paraboschi EM, Mantovani A, Duga S. ACE2 and TMPRSS2 variants and expression as candidates to sex and country differences in COVID-19 severity in Italy. Aging (Albany NY) (2020) 12:10087-98. doi: 10.18632/aging.103415

82. Cao Y, Li L, Feng Z, Wan S, Huang P, Sun X, et al. Comparative genetic analysis of the novel coronavirus (2019-nCoV/SARS-CoV-2) receptor ACE2 in different populations. Cell Discovery (2020) 6:11. doi: 10.1038/s41421020-0147-1

83. Ortiz-Fernández L, Sawalha AH. Genetic variability in the expression of the SARS-CoV-2 host cell entry factors across populations. Genes Immun (2020) 21:269-72. doi: 10.1038/s41435-020-0107-7

84. Elisa B, Rossella T, Ottavia S, Andrea C, Giovanni B, Alessandro B, et al. ACE2 gene variants may underlie interindividual variability and susceptibility to COVID-19 in the Italian population. medRxiv (2020) 28:1602-14. doi: 10.1101/2020.04.03.20047977 04.03.20047977

85. Vargas-Alarcón G, Posadas-Sánchez R, Ramírez-Bello J. Variability in genes related to SARS-CoV-2 entry into host cells (ACE2, TMPRSS2, TMPRSS11A, ELANE, and CTSL) and its potential use in association studies. Life Sci (2020) 260:118313. doi: 10.1016/j.lfs.2020.118313

86. Hou Y, Zhao J, Martin W, Kallianpur A, Chung MK, Jehi L, et al. New insights into genetic susceptibility of COVID-19: An ACE2 and TMPRSS2 polymorphism analysis. BMC Med (2020) 18:216. doi: 10.1186/s12916-020$01673-\mathrm{Z}$

87. Othman H, Bouslama Z, Brandenburg JT, da Rocha J, Hamdi Y, Ghedira K, et al. Interaction of the spike protein RBD from SARS-CoV-2 with ACE2: Similarity with SARS-CoV, hot-spot analysis and effect of the receptor polymorphism. Biochem Biophys Res Commun (2020) 527:702-8. doi: 10.1016/j.bbrc.2020.05.028

88. Delanghe JR, Speeckaert MM, De Buyzere ML. The host's angiotensinconverting enzyme polymorphism may explain epidemiological findings in COVID-19 infections. Clin Chim Acta (2020) 505:192-3. doi: 10.1016/ j.cca.2020.03.031

89. Bosso M, Thanaraj TA, Abu-Farha M, Alanbaei M, Abubaker J, Al-Mulla F. The Two Faces of ACE2: The Role of ACE2 Receptor and Its Polymorphisms in Hypertension and COVID-19. Mol Ther - Methods Clin Dev (2020) 18:321-7. doi: 10.1016/j.omtm.2020.06.017

90. Gómez J, Albaiceta GM, García-Clemente M, López-Larrea C, AmadoRodríguez L, Lopez-Alonso I, et al. Angiotensin-converting enzymes (ACE, ACE2) gene variants and COVID-19 outcome. Gene (2020) 762:145102. doi: 10.1016/j.gene.2020.145102

91. Ellinghaus D, Degenhardt F, Bujanda L, Buti M, Albillos A, Invernizzi P, et al. Genomewide Association Study of Severe Covid-19 with Respiratory Failure. N Engl J Med (2020) 283:1522-34. doi: 10.1056/NEJMoa2020283 NEJMoa2020283

92. Shelton JF, Shastri AJ, Ye C, Weldon CH, Filshtein-Somnez T, Coker D, et al. Trans-ethnic analysis reveals genetic and non-genetic associations with COVID-19 susceptibility and severity. medRxiv (2020). doi: 10.1101/ 2020.09.04.20188318

93. Zhao J, Yang Y, Huang H, Li D, Gu D, Lu X, et al. Relationship between the ABO Blood Group and the COVID-19 Susceptibility. Clin Infect Dis (2020) ciaa1150. doi: 10.1093/cid/ciaa1150

94. Wu Y, Feng Z, Li P, Yu Q. Relationship between ABO blood group distribution and clinical characteristics in patients with COVID-19. Clin Chim Acta (2020) 509:220-3. doi: 10.1016/j.cca.2020.06.026

95. Abdollahi A, Mahmoudi-Aliabadi M, Mehrtash V, Jafarzadeh B, Salehi M. The novel coronavirus sars-cov-2 vulnerability association with abo/rh blood types. Iran J Pathol (2020) 15:156-60. doi: 10.30699/ijp.2020.125135.2367

96. Cooling L. Blood groups in infection and host susceptibility. Clin Microbiol Rev (2015) 28:801-70. doi: 10.1128/CMR.00109-14

97. Pairo-Castineira E, Clohisey S, Klaric L, Bretherick AD, Rawlik K, Pasko D, et al. Genetic mechanisms of critical illness in Covid-19. Nature (2020) 591:92-8. doi: 10.1038/s41586-020-03065-y

98. Sommeijer DW, Reitsma PH. Genetic Risk Factors for Disseminated Intravascular Coagulation. In: Madame Curie Bioscience Database [Internet]. Austin (TX): Landes Bioscience (2013). Available at: https:// www.ncbi.nlm.nih.gov/books/NBK6069/

99. Takahashi K, Chang WC, Takahashi M, Pavlov V, Ishida Y, La Bonte L, et al. Mannose-binding lectin and its associated proteases (MASPs) mediate coagulation and its deficiency is a risk factor in developing complications from infection, including disseminated intravascular coagulation. Immunobiology (2011) 216:96-102. doi: 10.1016/j.imbio.2010.02.005

100. de Sousa E, Ligeiro D, Lérias JR, Zhang C, Agrati C, Osman M, et al. Mortality in COVID-19 disease patients : Correlating the association of major histocompatibility complex (MHC) with severe acute respiratory syndrome 2 (SARS-CoV-2) variants. Int J Infect Dis (2020) 98:454-9. doi: 10.1016/j.ijid.2020.07.016

101. Pretti M, Galvani R, Fioravanti Vieira G, Bonomo A, Bonamino M, Boroni M. Class I HLA Allele Predicted Restricted Antigenic Coverages for Spike and Nucleocapsid Proteins Are Associated With Deaths Related to COVID-19. Front Immunol (2020) 11:565730. doi: 10.3389/fimmu.2020.565730

102. Hu B, Huang S, Yin L. The cytokine storm and COVID-19. J Med Virol (2021) 93:250-6. doi: 10.1002/jmv.26232

103. Ahluwalia JK, Hariharan M, Bargaje R, Pillai B, Brahmachari V. Incomplete penetrance and variable expressivity: Is there a microRNA connection? BioEssays (2009) 31:981-92. doi: 10.1002/bies.200900066

Conflict of Interest: The authors declare that the research was conducted in the absence of any commercial or financial relationships that could be construed as a potential conflict of interest.

Copyright (c) 2021 Fricke-Galindo and Falfán-Valencia. This is an open-access article distributed under the terms of the Creative Commons Attribution License (CC BY). The use, distribution or reproduction in other forums is permitted, provided the original author(s) and the copyright owner(s) are credited and that the original publication in this journal is cited, in accordance with accepted academic practice. No use, distribution or reproduction is permitted which does not comply with these terms. 